\title{
Utilization of Geographic Information Systems in Ecological Studies
}

\author{
Dr. Necdet Incedayı
}

\begin{abstract}
Geographic Information Systems (GIS) is increasingly being utilised in spatial location and ecologic based inventory, planning and management studies. GIS have techniques and methods that enable detecting numeric spatial data and studying on, recording, reordering, modelling, analysing, and presenting these data in alphanumeric or graphic forms. In addition and more importantly, GIS helps users detect spatial correlation of geometric and nongeometric data in complex and logical context (Richter et al, 1997). This feature is highly important for rendering complicated-complex phenomenal structure and spatial correlation in ecological studies into objective and quantifiable degree ecological studies (Miller and Rogan 2007). In this study, some ecological features of Kocasu Stream Delta and Vicinity are shown in GIS base.
\end{abstract}

Keywords: Geographic Information Systems (GIS).

\section{INTRODUCTION}

\subsection{What is GIS?}

GIS is widely perceived as integration of geography with database systems, however, the origin of GIS consists of various disciplines and sciences, such as computer sciences, geography, mathematics, decision making, statistics, remote sensing, engineering, data processing, planning, ecological sciences, landscape architecture, modelling, research and cartography. Tecim (2008, p.54) remarks that as GIS is a specific information system utilised in executing and revealing models on geographical facts, contribution of various disciplines is necessary for sufficiently efficient, strong and flexible practice.

According to ESRI (Economic and Social Reseacrh Institute) (2013), one of the Pioneer institutions of the sector, GIS integrates hardware, software and data in order to capture, manage, analyse and reveal information geographically referred. It enables tracing, understanding, interrogating, intrpreting and visulalisation of data through varous means and tools such as maps, globes, reports schedule format dispositions. Looking at fast understandable and easily sharable data, it helps solving problems and replying questions. In addition, GBS technology can be integrated with information systems.

\subsection{Where is GBS Utilised?}

Nowadays, geography and data defining geography is part of our daily life. Almost all of our Daily decisions are affected, restricted and managed by these data. Gradually diminishing natural resources despite rapid population growth causes vital and irreversible effects on earth. Interrelated causes such as depletion of the ozon layer, destruction of tropic jungles, diminishing plant diversity, acid rains, greenhouse effect, increasing disturbing effect of toxic chemicals on natural balance, urbanization agricultural areas, and migration affect social and economic structure. Just as in macroscale decision making processes, these important donnee have to be rapidly understood by scientists and decision makers in providing and managing minimum urban utilities such as electricty, water, urban infrastructure, and minimizing the affects of both human caused and natural disasters. Essential objective here is developing alternatives, and simultaneously considering various alternatives so as to speed up the whole process. This could only be realised by utilisation of Geographic Information Systems.

Geographic Information Systems provide a structure which could be utilised in all areas where there is geographical data. Considering how wide the definion of geographical data, it is natural to have a considerably long list on utilisation areas of GIS. It is even possible to say that GIS has different 
utilisation areas directly proportional to its number of users. Research show that GIS technology is utilised in basic areas, which are:

- Producing Maps and Planning: These systems provide great convenience and ease for planning sector as they enable studying with updated data and processing complex data very rapidly. Thus, a sound planning could be done. The system is also used in improving printing quality of maps, and production of plans, for instance, individual distribution of planimetric, topographic, marin, aerial and thematic maps and other similar cartographic productions, or production of such materials to be part of other printed or electronic documents.

- Selecting Route and Navigation: Experts monitoring, analysing and screening events in health and security well understood advantages of GIS. GIS provide fast, continuous, highly reliable and economic implementation of such services. The system is utilised for selecting the optimum route in a network according to detected criteria, and in practices such as selecting routes for emergency service vehicles, for vehicles carrying dangerous goods, and taxis when necessary. Actually, many GIS applications comprise two or more basic practices. It is necessary to state that among available GIS softwares, yet there is no software to support all 9 types of basic practices. Through a user perspective approach while categorising GIS scopes of application, it is seen that 20 different user groups currently utilise GIS Technologies.

- Educational Administration,

- Engineering,

- Environment,

- Mineral exploration and mining,

- Poltical administration,

- Public Security,

- Press and Media,

\subsection{Examples of GIS-Based Ecological Applications}

\subsubsection{Location and General features of Kocasu Stream Delta and Immediate Vicinity}

North of the study area is bordered with Marmara Sea. Border to the East, West and South is defined by close hinterland of the delta. Kocasu Stream Delta, also named as Kocasu Delta by some sources, is located on Southern Coast of Marmara Sea, within the borders of Bursa Province, it is approximately $30 \mathrm{~km}$ far from Karacabey District is $30 \mathrm{~km}$.

Dominated by waves, with a sandy lithology and arcurate geometry, Kocasu Stream Delta and its immediate vicinity (Fotograph 1) is located in Southern Marmara Section of Marmara Region in terms of geographical regions, and with regard to administrative units, it remains within Karacabey Distrcit of Bursa Province. In terms of terrestrial coordinates, Kocasu Stream Delta is located between $40^{\circ} 39^{\prime \prime} 83^{\prime \prime}-40^{\circ} 25^{\prime} 00^{\prime \prime}$ Northern Latitudes, and $28^{\circ} 3707^{\prime \prime}-28^{\circ} 64^{\prime} 50 " E a s t e r n$ Longtitudes. The area is in the scope of UTM 35 Zone, and in 44610 00-4472800 ordinates (y), and 516928-638201 apsis ( $\mathrm{x}$ ) axis.

Distance of study area to Bursa city centre is $66 \mathrm{~km}$, whereas its distance to İstanbul is $209 \mathrm{~km}$, to Ankara $440 \mathrm{~km}$, and to İzmir $260 \mathrm{~km}$. The area is accessed through D 200 highway.

Karadere Stream flowing from Manyas Lake (Bird Lake), Uluabat Stream flowing from Uluabat Lake, and Nilüfer Stream flowing through Bursa constitute Kocasu Stream (Susurluk River), which flows through Kocasu Stream Delta and flows into Marmara Sea. 


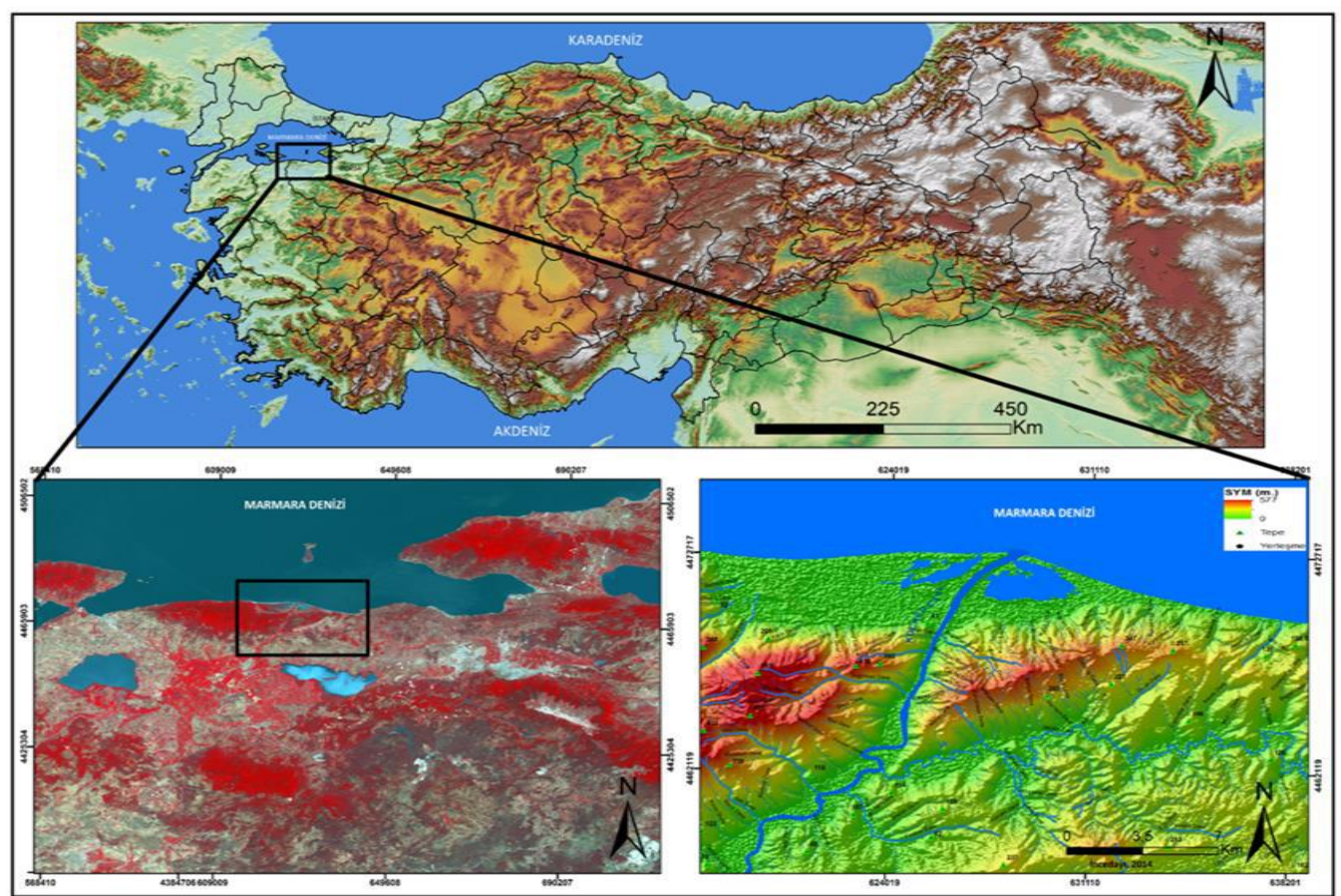

Fig1. Location of the Study Area

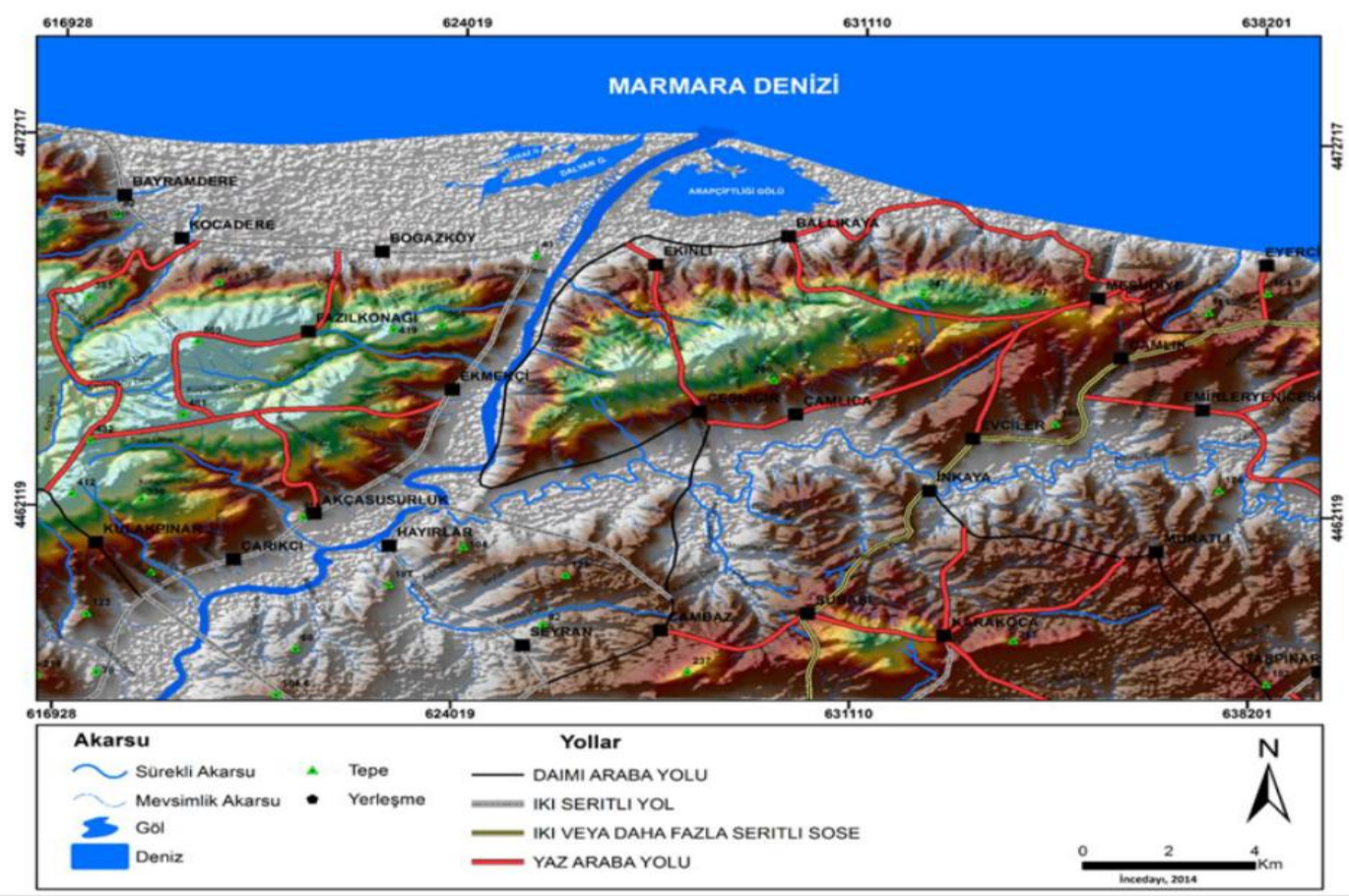

Fig2. General Physical View of the Study Area

Dalyan, Poyraz and Arapçiftliği lagoons are located in Kocasu Stream Delta and vicinity. These lagoons are surrounded by reedy areas, marhes and floodplain forests. Delta is decorated with floodp forests composed of ash, alder and willow trees most of which covered with 1 metre deep water, and aquatic plants such as water lilies, water orchids, loddon lilies, and buther's brooms.

Until 20 years ago, snake fish used to pass through crawling the sand dune between the sea and lake at Kocasu Stream Delta during their spawning period, and migrate to coats of Gulf of Mexico passing through Marmara Sea, Aegean Sea, Mediterranean and Atlantic Ocean. Lagoons in this area and ecological system at Kocasu Stream Delta have been seriously destroyed due to extensive pollution and increasing chemical wates especially at Nilüfer Stream and Susurluk River. Kocasu Stream Delta next to floodplain forest was declared "Wetland To Be Protected", however, reproductionand shelter of living creatures in the area did not achieve to desired level as extensive pollution at stream delta diminished oxygen in the water. There are efforts for including the area to Ramsar Convention. 
Kocasu Stream Delta, hosting many types of birds such as black stork, ferruginous pochard, clooared pranticole, snowy plover, little bittern, night heron, squacco heron, little egret, grey heron, swan, mallard, garganey, red crested pochard, common pochard, white tailed eagle, greater spotted eagle, white headed duck, black throated diver, coot, oystercatcher, common tern, little tern and many types of woodpeckers, also hosts pygmy cormorants and white pelicans during migration seasons.

Kocasu Stream Delta, as a valuable ecosystem although a natural protected area, is currently coming under threats of pollution and illegal commercial activities. Floodplain forests in the delta and other natural structures are being destroyed for acquisition of agricultural land and poplar tree groves, trees are illegally being cut down, both coastal dunes and underwater sand in shallow water is illegally being taken and carried away.

The major problem in the delta is that Nilüfer Stream carries the wastes of Bursa province, and wastes of industrial facilities and settlement areas alongside Susurluk River are carried by the river, and these wastes mix to Kocasu Stream delta and vicinity and causes a serious pollution, which treatens the living ecosystem in the delta. Color of the sea where Kocasu Stream flows into sea time to time becomes brown due to excessive pollution of river water. New waste water treatment projects to increase the capacity of Eastern and Western Waste Water Treatment Facilities, which refine 60\% of waste water discharged to Nilüfer Stream are still pending. In addition, Marmara Sea is only $10 \mathrm{~km}$ away from Nilüfer Stream. If treated water at Eastern and Western West Water Treatment Facilities is discharged into Marmara Sea instead of Nilüfer Stream, pollution problem of the stream could be solved. So, farmers in the area could have the chance of watering their farmlands with a cleaner water, and water fowls will be nourished in a cleaner aquatic environment. Moreover, waste and rubbish of Yeniköy and nearby settlements, and domestic wastes arising from tourism activities are carried to dumpside inside the delta, approximately $1 \mathrm{~km}$ away from Yeniköy. These piles of rubbish among floodplain forests and habitat like coastal sand dunes cause a vary bad visual pollution. Rubbish such as nylon bags sprading and scattering around are carried by wind alongside the coast and floodplain, and pollutes the delta to a great extent. Although water at Dalyan and Poyraz lakes shrink to degree during summer time, remaining water is still sufficient to meet all necessities of birds. However, water of Arapçiftliği Lagoon totally shrinks during summer. So, two small islets in the lagoon could not be sufficiently used by birds.

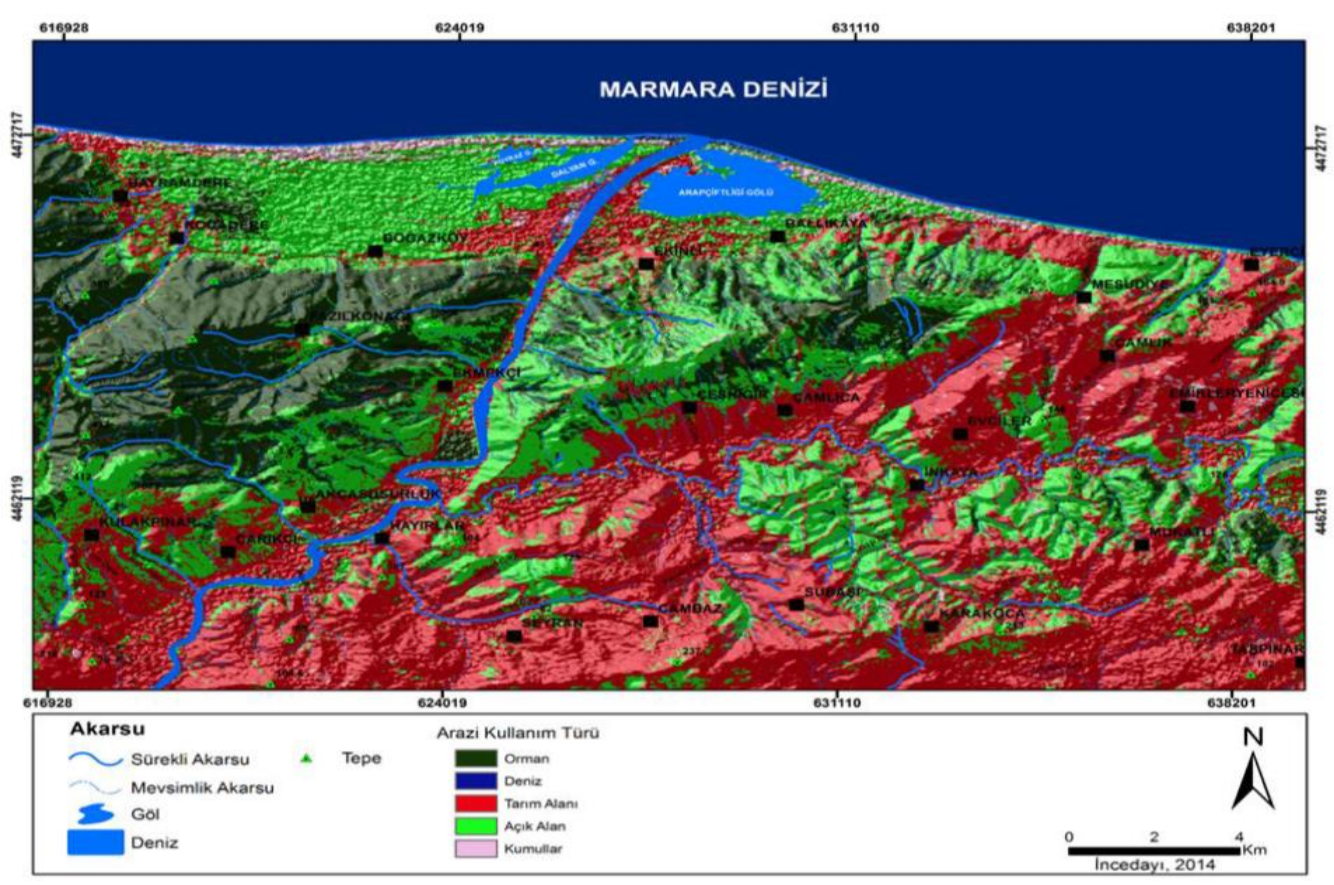

Fig3. Land Use Properties of Study Area

Poeple living in the study area work in agriculture, animal husbandry, fishing, forestry aand tourism sectors. Settlers of Güngörmez, Örencik, Şahmelek, Yarış, Bayramdere, Kurşunlu and Boğazköy villages engage in forestry, other villages are not engaged in this sector. Pine nut provides considerable contribution to family budgets in Şahmelek and Boğazköy villages. Besides paddy farming, bayleaf and linden are among subsidiary products that people engane in (Figure 3). 


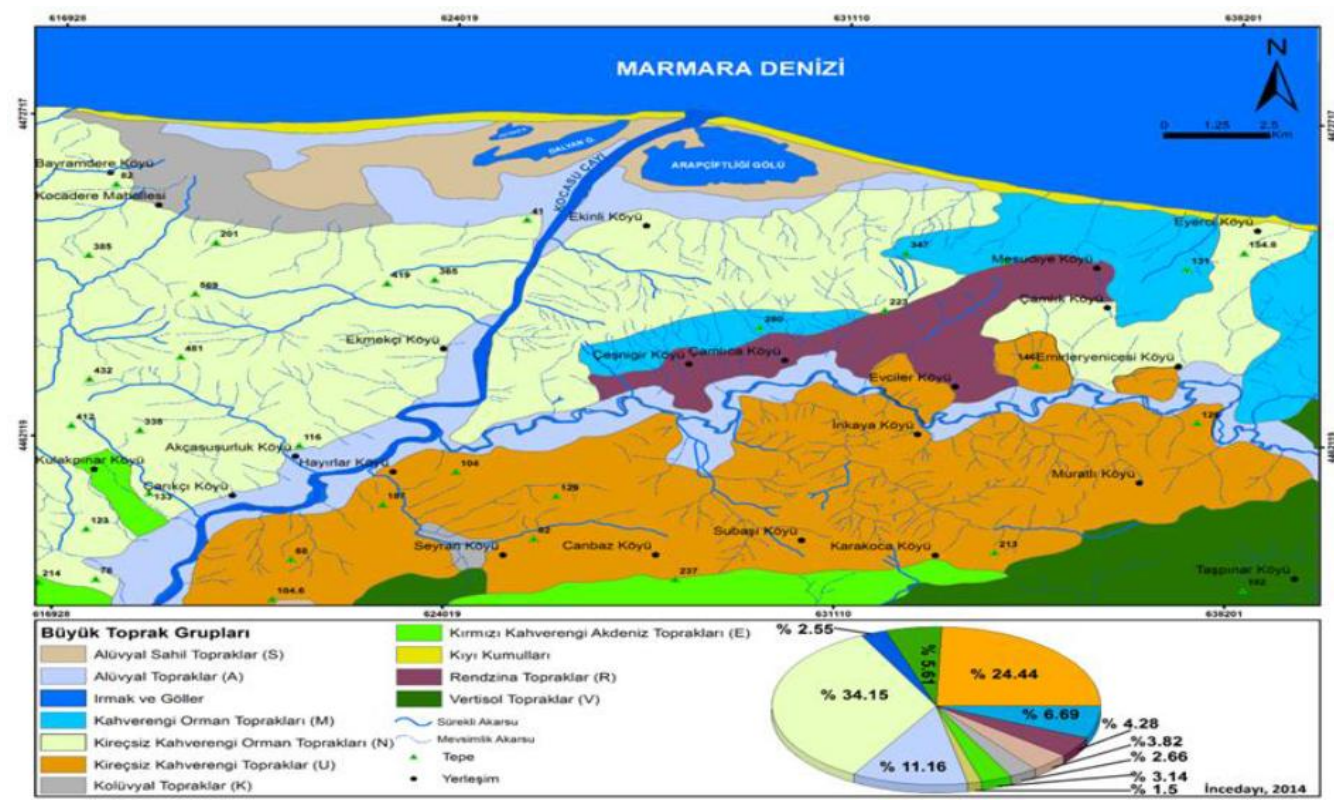

Fig4. Soil Map of Study Area

Upper zone of litosphere is composed of organic soils on inorganis rocks. In this respect, soil is considered as an element of biosphere. Prevailing soil types in the study area are defined as; alluvial soils, colluvial soils, non-calcareous brown forest soils, red Brown mediterranean soils and rendzina (Figure 4).

Natural vegetation of the study area is composed of forests, shrubberies and herbaceous formations. Particularly, moist forests appear on northern slope of Karacadag and dry forests on southern slope. Pseudoscrub on coastal regions of mosit forests, and scrub formations at lower regions of dry forests are remarkable.

Regarding the forest ecosystem, pseudoscrub types cover lower layer of 0-400 metres, whereas forest composed of leaved trees, especially chestnut and linden seen at upper layer (ash, alder and willow trees at floodplain), forest zone dominated by oak and beech trees starts after $400 \mathrm{mt}$ height. Generally, pure beech tree stands seen at tis zone, eventhough other leaved tree types encountered.

Woody plants except for poplar and willow trees at waterfront areas of plain base diminished to a vast scale, natural steppe in most areas turned into agricultural lands. Delta area edges into a hydrobiome, where ash, görse, plane and alder trees seen. A large part of this area is covered with water during winter times (Atalay, 1994).

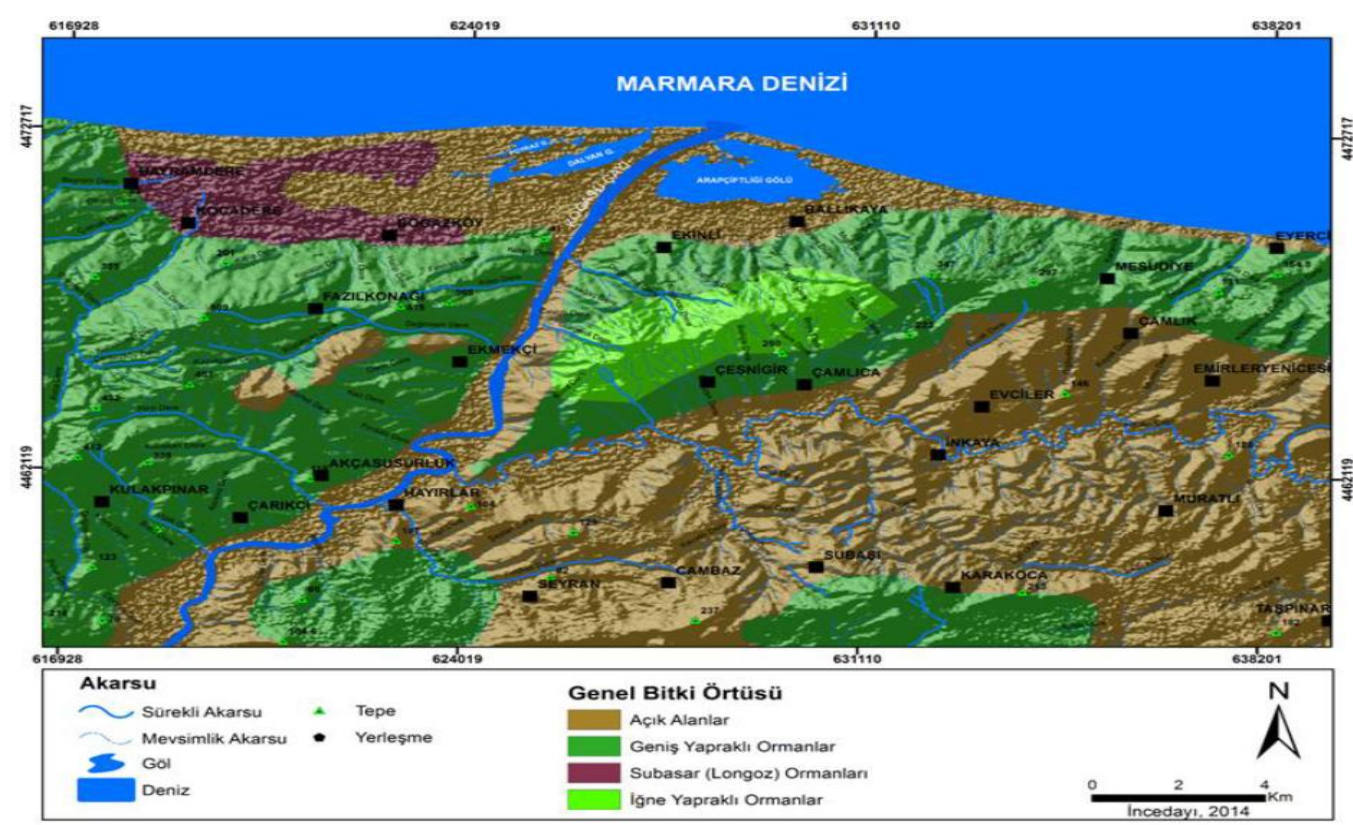

Fig5. Generalized Forest Map of the Study 
Kocasu Stream Delta, hosting many types of birds such as black stork, ferruginous pochard, clooared pranticole, snowy plover, little bittern, night heron, squacco heron, little egret, grey heron, swan, mallard, garganey, red crested pochard, common pochard, white tailed eagle, greater spotted eagle, white headed duck, black throated diver, coot, oystercatcher, common tern, little tern and many types of woodpeckers, also hosts pygmy cormorants and white pelicans during migration seasons (Figure $6)$.

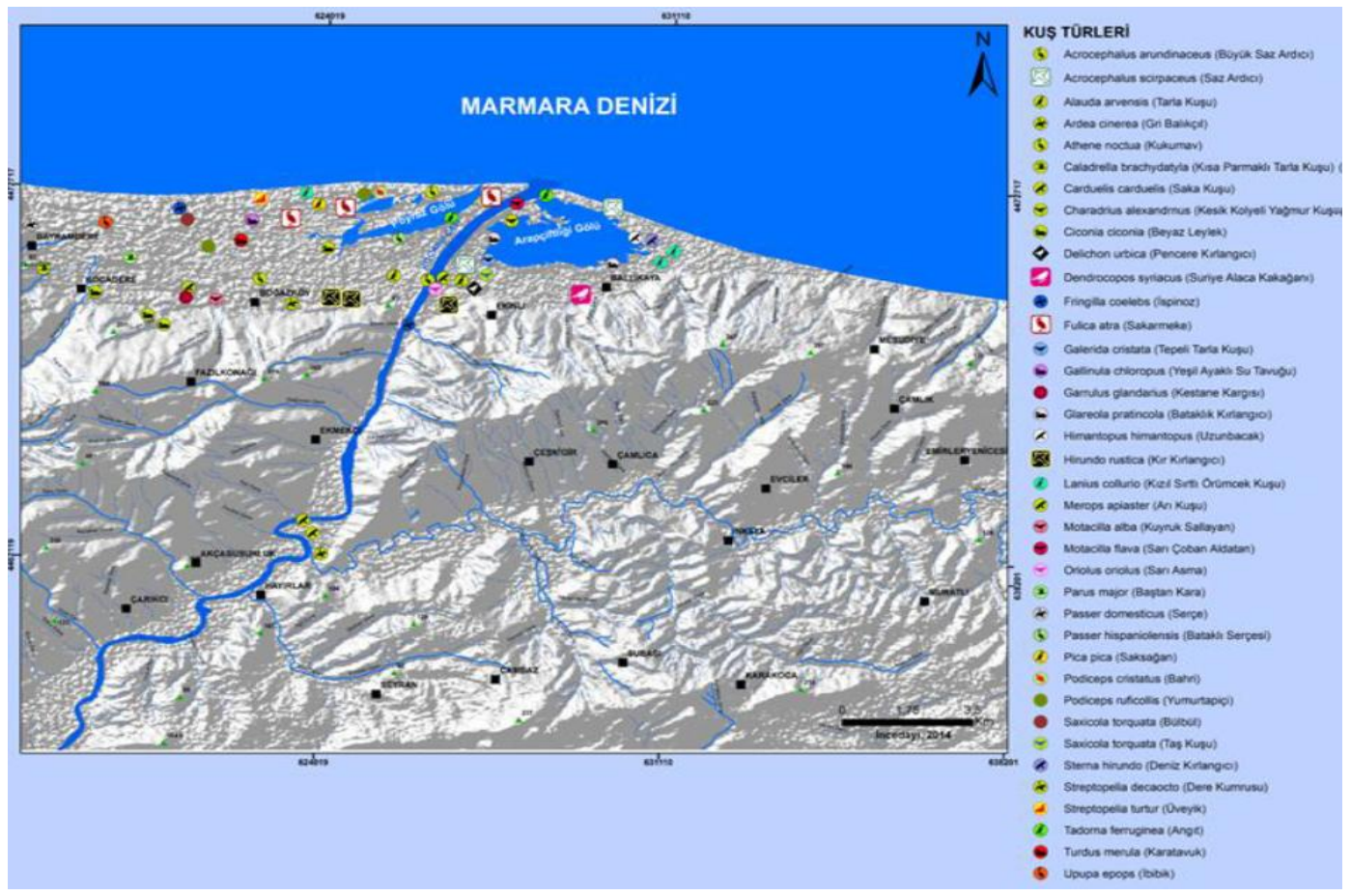

Fig6. Birds Living in the Study Area

Eken et al discovered that among birds living in the study area, 38 species are residents, 11 are winter migrants, 22 are summer migrants and 16 of the species are transit birds. 27 of the species could not be classfies as they could only be observed once or twice on site. Findings confirm that 28 species breed at study area. Among 114 species, 46 are aquatic birds of which 12 breed at study area (Eken et al, 2006).

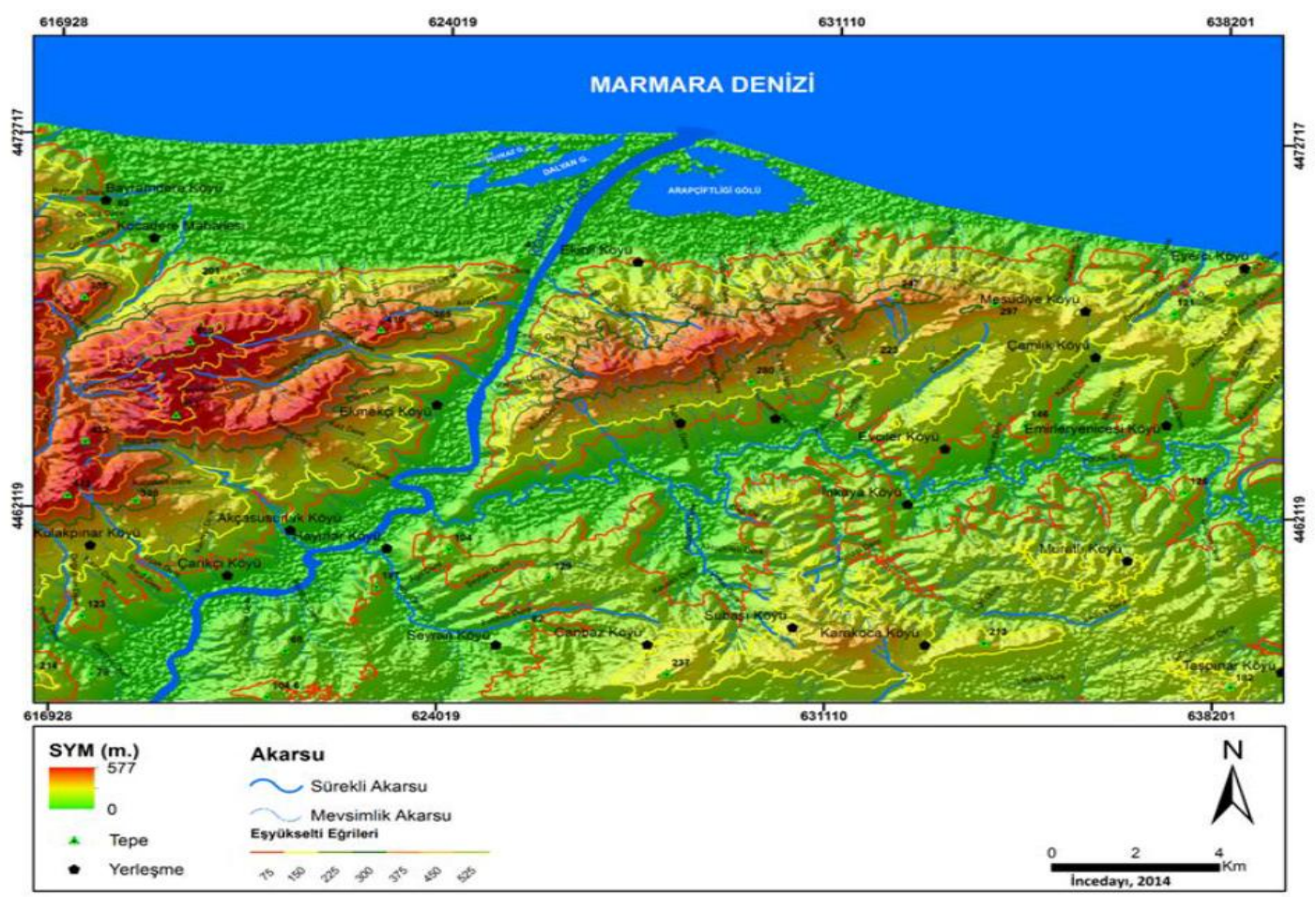

Fig7. Topographic Map of the Study Area 
Elevation of the study area starts from sea level, and reches up to 577 at southern heights, in the vicinity of the area. Thus, height amplitude is $\mathbf{5 7 7}$ metres. However, elevation does not exceed 30 metres in the delta area.

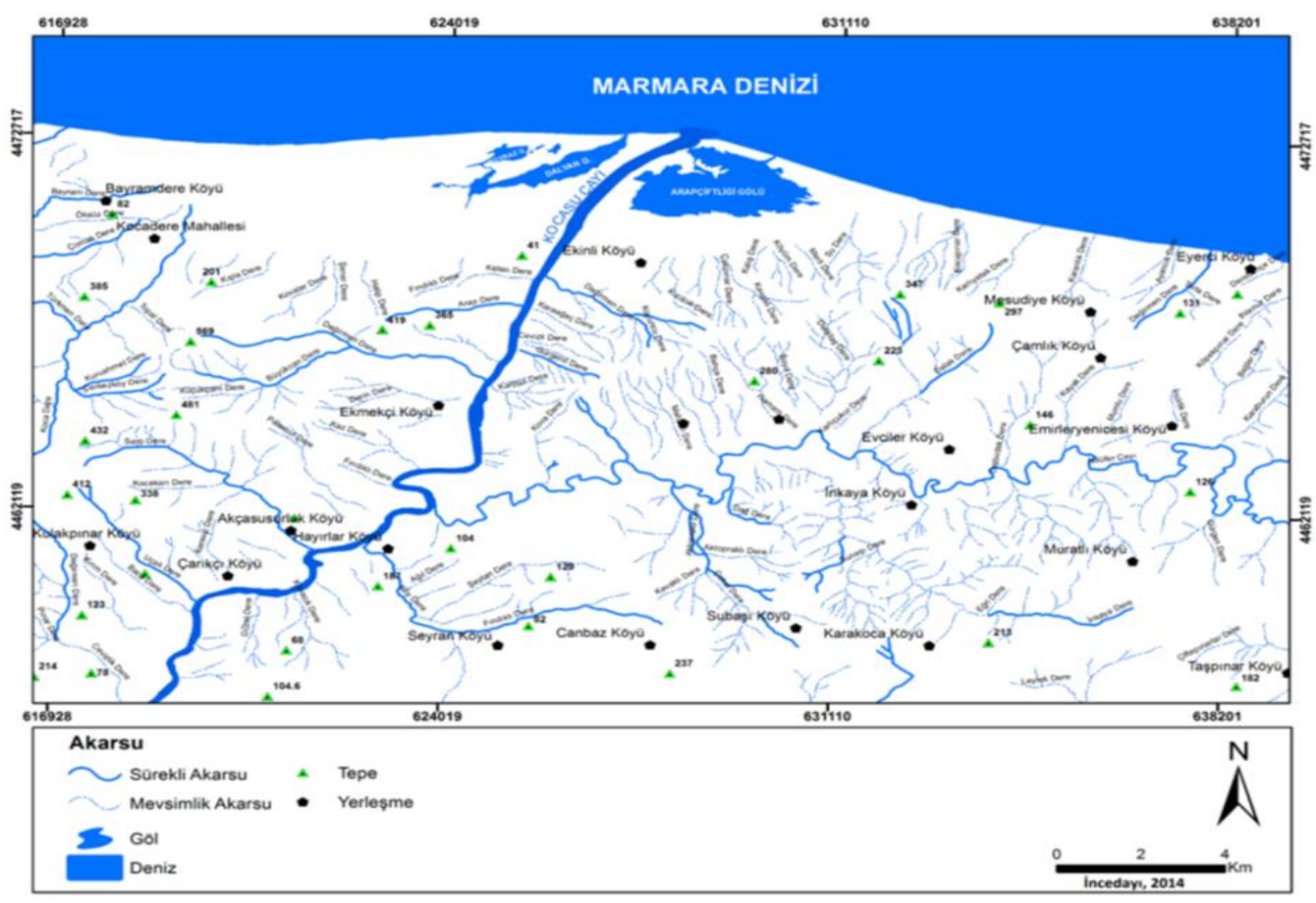

Fig8. Hydrographic Map of the Study Area

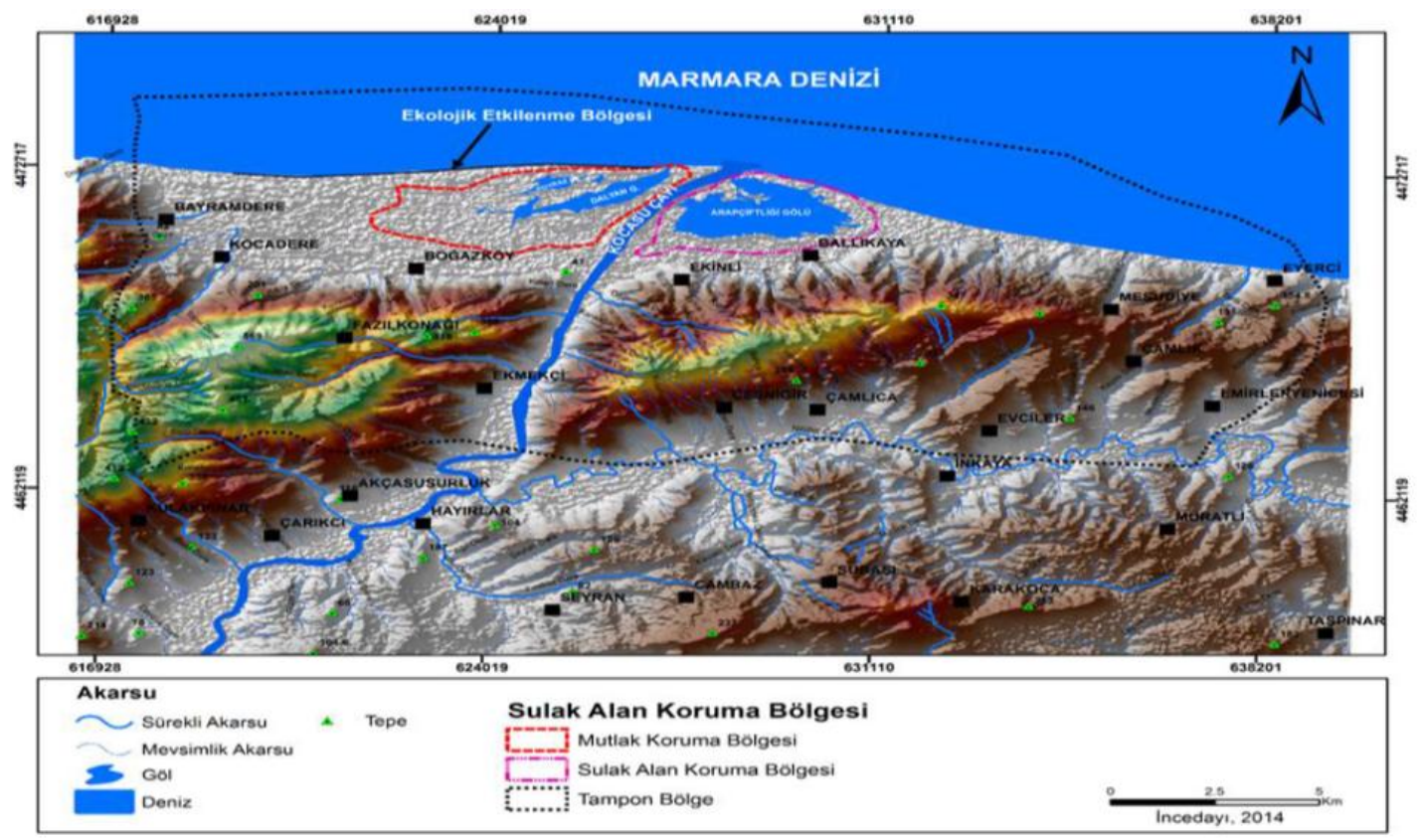

Fig9. Wetland Conservation Areas of the Study Area

\subsection{Benefits of GIS in Ecological Studies}

Ecology in the broad sense is the science studying the interactions among animal, plant, soil, water and air, with their environment and human beings. Environment is studied in two grous, abiotic and biotic. In this regard, ecology is is under the effect of biotic and abiotic factors, and explains the relation between organisms and the environment. Sciences such as geology, meteorology, hydrology, oceanography, climatology, geomorphology study the physical environment. Biologic environment on the other hand, is researched and examined by anthropology, sociology, biology and ecology. The environment in this respect not only covers physical features and aspects, but interaction and relation of organisms with their environment as well. 
Ecology and environment are two widely used terms, however, definition of the terms are sometimes confused. Human beings pollute the air breathing in and water drinking. If human beings exert effort to refine the air and water through physical enviroment features, then this is related to the environment. However, if this effort is carried out considering the plants and animals affected by this pollution, then it becomes an ecological issue. Keeping the earth at a stable equilibrium that could nourish diverse living creatures is highly important. This equilibrium cannot be work of a non living substance. Events that are ecologically related to living creatures occur at atmosphere, hydrosphere, litosphere, and biosphere. Population, community and ecosystems that current ecology place great emphasis compose the living unions in the biosphere.

Coastal sand dune of Kocasu Stream Delta is one of the internationally important natural resevre areas. Many sand dune plants grow on wide shore line. Among these sand dune plants, there are also endemic species growing only in Turkey.

Atriplex tatarica is an endemic specy, and according to IUCN criteria, it is categorised as "Critic CR" in regional red list (Table 7) Pancratium maritimum and Rhododendron ponticum were categorised as "Endangered-EN". Elymus farctus, Leucojum aestivum and Lotus suaveolens are in "Vulnerable-VU" category. Teucrium chamaedrys subsp. tauricolum is an endemic specy, described as Low Concern-LC".

\begin{tabular}{|c|c|c|c|c|}
\hline Takson Name & Turkish adı & Endemik & $\begin{array}{c}\text { Tek nokta } \\
\text { endemiği }\end{array}$ & Bölgesel Kırmızı Liste \\
\hline Atriplex tatarica & Tatar karapazısı & Endemik & 0 & Kritik -CR \\
\hline Centaurea spinosa & Peygamber çiçeği & 1 & 0 & $\begin{array}{c}\text { subsp. tragacanthoides } \\
\text { Endemik ve DD }\end{array}$ \\
\hline Elymus farctus & Kum ayrığı & 0 & 0 & $\begin{array}{c}\text { subsp. bessarabius var. } \\
\text { striatulus, subsp. Rechingeri } \\
\text { Düşük riskli-LC }\end{array}$ \\
\hline Lavandula stoechas & $\begin{array}{c}\text { Yabani üzüm asması, } \\
\text { Karabaş otu, Keşiş } \\
\text { otu }\end{array}$ & 0 & 0 & $\begin{array}{c}\text { Subsp. cariensis Endemik, } \\
\text { Tehdite Yakın-NT }\end{array}$ \\
\hline Leucojum aestivum & Göl soğanı & 0 & 0 & Hassas-VU \\
\hline Lotus suaveolens & Kum zambağ1 & 0 & 0 & Hassas-VU \\
\hline Pancratium maritimum & Ormangülü & 0 & 0 & Tehlikede-EN \\
\hline R.ponticum & Dalakotu & $\begin{array}{c}\text { tauricolum } \\
\text { endemik }\end{array}$ & Endemik & Düşük riskli-LC \\
\hline Teucrium chamaedrys & nubsp. & \\
\hline
\end{tabular}

According to IUCN criteria, among 114 species identified in the delta, 110 are in "Low Concern-LC" category, 2 are in "Vulnerable-VU" and 1 is in "Near Threat-NT" category (Table 7). Species classified as "Vulnerable-VU" category are elecanus crispus (dalmatian pelican) ve Aquila clanga (spotted eagle). Aythya nyroca (ferruginous pochard) is categorised as "Near Threat-NT". The area gained Importan Bird Area (IBA) status as the area is a breeding zone for populations of Ciconia nigra (black stork), Glareola pratincola (collared pranticole), Charadrius (Tübitak, 2009).

Tablo8. Endangeted Animal Species in the Study Area

\begin{tabular}{|c|c|c|c|c|c|c|}
\hline Latince Adı & Türkçe Adı & Tür grubu & Endemik & $\begin{array}{c}\text { Küresel } \\
\text { Tek nokta } \\
\text { endemiği } \\
\text { Kırmızı } \\
\text { Liste } \\
\text { Kategorisi }\end{array}$ & $\begin{array}{c}\text { Ulusal ya da } \\
\text { Bölgesel } \\
\text { Kırmızı Liste } \\
\text { Kategorisi }\end{array}$ \\
\hline Capreolus capreolus & Karaca & MEMELİ & 0 & 0 & $L C$ & (VU) \\
\hline Larus cachinnans & Gümüşi martı & KUŞ & 0 & 0 & $L C$ & EN \\
\hline Aythya nyroca & Pasbaş patka & KUŞ & 0 & 0 & $N T$ & VU \\
\hline Burhinus oedicnemus & Kocagöz & KUŞ & 0 & 0 & $L C$ & VU \\
\hline Sterna nilotica & Gülen sumru & KUŞ & 0 & 0 & $L C$ & VU \\
\hline
\end{tabular}

As GIS is utilised more and more, two major benefits appeared. The first is the quantitative benefits, which could be measured with economic terms. Second one is the qualitative benefits, eventhough these cannot directly be meaured, results of a GIS Project could be assessed and evaluated with its economic value. GIS programmes could differ in accordance with size and quantity of work 
organizations in diverse organizations, flow rate of information automations, problems existing and complexity and size of registry. Definable quantitative benefits depend on amount and quality of data and how continuance of these data provided.

In many countries, couriers, inner-city transportation agencies, mailing operators and many other service agencies are controlled by GIS, which helps efficient use of time and labour force. Utilisation of GIS provides below benefits:

- Fast and easy utilisation

- More efficient production and inventory management

- Access to connected and unconnected data

- Opportunity of nearby and distant data interrogating during practices.

- Critical data analysis

- Supporting sectors such as engineering, planning, real estate, topography, hydrography, land use and taxation maps.

- emergency reponse analysis

- High quality printing services

- Finding address and conjugation

- Opportunity of updating and redefining data

- Opportunity of using vectors and raster methods.

- Opportunity of examining closed area or buffer zone

- Identifying and accepting sounds and GPS

- Opportunity of increasing map layers by the help of pan and zoom .

- Used for Screen data reseting, changing symbols, labeling and dot density.

- It is possible to see any type of figüre formats.

- It is possible to interrogate SQL through database.

- It is possible to make special analysis and interrogation.

- Used in finding geographical addresses. Adres coğrafyasını bulma

- Helps timely arrival to incidents (AM/FM/GPS/CBS)

- Includes many information in its wide data set such as streets, populations, zip codes, country borders

- It includes data distribution.

\section{RESUltS}

Sustainable management principles in all areas should be carried into effect in the the study area. To do this, partnership programs with NGOs focusing on ecology, environmental protection and tourism should be developed and realised by definig and sharing priorities, exchanging information, competency and success, and global partnership programs should be organised and implemented so as to improve competence and efficiency.

Factors threatening the ecosystem in the study area, especially threating the biological diversity dramatically should be focused, and these factors should be identified and refined. Actions plans should be prepared and implemented in order to stop destruction in the study area, prevent maltreatment of the environment, recover destruction and protect cultural, biological and ecological diversity of the area.

In order to develop influence of environment policy developers on environment in a positive way, efforts to establish and develop relations among relevant agencies and institutions should be carried 
out. Education and communication programs for human beings on sustainable regional development, tourism from an environmental and social responsibility respect, and efficient environmental education; these programs should be programmed through a democratic and equality perspective. Such programs will help creating social awareness.

This study tries to explain methods and procedures while utilising GIS in ecological studie, and which factors should be considered in this process. In addition, some features of Kocasu Stream Delta are shown on GIS base. More efficient and reliable data could be obtained by utilising benefits of GIS.

\section{REFERENCES}

Atalay, İ. (2008): Ecosystem Ecology and Geography, İzmir.

Miller, J., Rogan, J. 2007. Using GIS and remote sensing for ecological mapping and monitoring, Mesev, V. (Ed.) Integration of GIS and Remote Sensing (233-268), John Wiley \& Sons

Güngöroğlu, Cumhur, 2011. Ecology Based Inventory, Utilisation of GIS in Planning and Management Applications, Union of Chambers of Turkish Engineers and Architectutes, GIS Congress, Antalya.

Güngöroğlu, C., Musaoğlu, N., Türkkan, M., Yöntem, O., Yılmaztürk, A., Çayır, G. 2008. Classification and Mapping of Biotope Types by Using GIS Supported Remote Sensing Techniques (Köprülü Canyon National Park Example), Directory of Western Mediterranean Forestry Research, Technical Bulletin, Issue: 31, Page 204, Antalya

Güngöroğlu, C., Sabuncu, R. 2008. Threatened Cypress Forest Ecosystems in the Mediterranean Region, EFE, R. Cravins, G., Öztürk, M., Atalay, İ. (ed.) Natural Environment and Culture in the Mediterranean Region (131-148), Cambridge Scholars Publishing, Newcastle

Güngöroğlu, C. 2008. Landscaping Approach in the Example of Germany, Journal of Directory of Western Mediterranean Forestry Research, V 1, Issue 9, 43-45

Tecim, V. 2008. Geographic Information System: Map Based Data Management, İzmir: Dokuz Eylül University

İnan, A, GIS ( Geographic Information System), İstanbul.

İncedayı N., (2015) Ecological Evaluation of Kocasu Stream Delta and Vicinity, Bursa

Lo, C.P. And Yeung, A.K.W., 2005. Concepts And Techniques Of Geographic Information Systems. Prentice Hall.

Longley, P.A., Goodchild, M.F., Maguire, D.J. And Rhind, W.W., 2011. Geographic Information Systems \& Science. Third Edition, John Wiley \& Sons, Usa.

Liang, S., Chen, C.Y., 1995, Conjunctive Use of GIS and Watershed Model for Environmental Protection, Proceedings of 1995 International Symposium on Geographic Information System for Environmental Protection, March 16-17, Taipei, Taiwan.

Keith C. Clarke, 2011. "Getting Started With Geographic Information Systems (5/E)". Pearson Education.

Jones, C.B. 1997. Geographical Information Systems And Computer Cartography. Longman. Uk.

Heywood, I., Cornelius, S., Carver, S., 2011. An Intorduction To Geographical Information Systems, Foutrh Edition, Pearson. England.

Ekinci,D., 2007, Estimating of Soil Erosion in Lake Durusu Basin Using Revised USLE 3d with GIS, Çantay Basımevi, İstanbul.

Ekinci,D., ve Ekinci, B., 2006, The Effect of Valley Networks on Erosion and a Sample for Using GIS Based Soil Erosion Risk Model, 18 th International Soil Meeting (ISM) on Soils Sustaining Life on Earth (Managing Soil and Technology); May 22-26, Proceedings, 465-472.

Ekinci, D., Karataş, A., 2012, Effects and of Human Beings on Natural Environment and Its. Example of Burbaz Wetland (Erzin-Hatay), National Geomorphology Symposium UJES 2012 Proceedings Book, Edt: Hüseyin KORKMAZ, Atilla KARATAŞ, p., 310-323. Color Ofset Matbaacilık, Hatay.

Ekinci, D., Ekinci B., Change of Land Use in Üsküdar and Current Features, International Üsküdar Symposium VI, 06-09 November 2008, Üsküdar, Türkiye. 
Ekinci, D., Ekinci, B., "Affects of Changing Ground Cover on Geography in Küçükçekmece Lake and Immediate Vicinity (İstanbul)", Turkish Geography Magazine, 47,131-146 (2006).

Ekinci, D., Cürebal, İ., 2006, Erosion Analysis by GIS Based RUSLE Method in Kızılkeçili Stream Basin, Turkish Geography Magazine, 47,115-130

Ekinci, D., Özşahin, E., Erosion Analysis by GIS Based RUSLE (3D) Method in Zeytinli Stream Basin (Balıkedir), International Syposium of Kaz Dağları (Ida Mountains) and Edremit , 5-7 May 2011, Edremit, Turkey

Yıldırım, Ü., Ekinci, D., 2003, Evaluation of Mass Movements by Geographic Information Systems, Example of Zonguldak and Ereğli Coasts, Sırrı Erinç Symposium 2003, 186-188, İstanbul.

Yomralığlu, T. 2000. Geographic Information Systems: Basic Concepts and Applications, Akademik Kitabevi, Trabzon.

Yomralığlu, T., 2011. "Geographic Information Systems: Basic Concepts and Applications (5th edition), Akademik Kitabevi, Trabzon. 